\title{
Paeoniflorin attenuates hepatic ischemia/reperfusion injury via anti-oxidative, anti-inflammatory and anti-apoptotic pathways
}

\author{
YE TAO $^{1}$, ZHIHONG WEN ${ }^{2}$, YINGQIAN SONG ${ }^{3}$ and HUI WANG ${ }^{1}$ \\ ${ }^{1}$ Department of Ultrasonography, The First Affiliated Hospital of Dalian Medical University, Dalian, \\ Liaoning 116011; ${ }^{2}$ Department of Radiology, The Fifth People's Hospital of Dalian, \\ Dalian, Liaoning 116021; ${ }^{3}$ Department of Nursing, The First Affiliated Hospital of \\ Dalian Medical University, Dalian, Liaoning 116021, P.R. China
}

Received September 19, 2014; Accepted August 6, 2015

DOI: 10.3892/etm.2015.2902

\begin{abstract}
During liver surgery, hepatic blood flow needs to be blocked in order to reduce bleeding, which inevitably results in hepatic ischemia/reperfusion injury (HI/R). Paeoniflorin (PF) is the main active ingredient of the traditional Chinese herbal medicine peony, which has been shown to exert anti-oxidative and anti-apoptotic properties. In the present study, a mouse model of HI/R was generated by clamping the hepatoportal vein, hepatic artery, and hepatic duct of BALB/c mice with a vascular clamp for $30 \mathrm{~min}$, followed by reperfusion for $6 \mathrm{~h}$ under anesthesia. Six mice in the three PF treatment groups $(5,10$ and $20 \mathrm{mg} / \mathrm{kg}$ ) were then injected with $\mathrm{PF}$, via the tail vein. A sham group, consisting of six mice that did not undergo the procedure, and a vehicle group, consisting of 6 mice that underwent the procedure but subsequently received injections of physiological saline only, were used as controls. Liver injury was indicated by serum levels of the enzymes alanine transaminase (ALT) and aspartate transaminase (AST). The activities of oxidative stress biomarkers, including superoxide dismutase (SOD), glutathione (GSH), glutathione peroxidase (GSH-PX) and malondialdehyde (MDA), were also measured. Furthermore, the activity of caspase-3 was analyzed in hepatic tissue using a commercial kit. Treatment with PF significantly attenuated HI/R injury histologically, as compared with the vehicle group. In addition, significant reductions in the serum levels of ALT and AST were observed in the PF-treated ischemic mice. Furthermore, treatment with PF enhanced the activities of hepatic tissue SOD, GSH and GSH-PX, but decreased the MDA content. Treatment of ischemic mice with $\mathrm{PF}$ markedly reduced the expression levels of inflammatory mediators, including nuclear factor- $\kappa \mathrm{B}$,
\end{abstract}

Correspondence to: Professor Hui Wang, Department of Ultrasonography, The First Affiliated Hospital of Dalian Medical University, 222 Zhong Shan Road, Dalian, Liaoning 116011, P.R. China

E-mail: huiwangmr@163.com

Key words: paeoniflorin, hepatic ischemia reperfusion injury, liver, anti-oxidative, anti-inflammatory, anti-apoptotic tumor necrosis factor- $\alpha$, interleukin (IL)-6, and IL-1 $\beta$, and decreased the HI/R injury-induced expression of caspase-3. The results of the present study suggest that PF attenuates the HI/R injury of mice via anti-oxidative, anti-inflammatory and anti-apoptotic activities.

\section{Introduction}

In liver surgery, hepatic blood flow is typically blocked in order to reduce bleeding; however, this inevitably results in hepatic ischemia/reperfusion injury (HI/R) (1). HI/R injury does not only cause significant direct damage to liver cells; but also alters the regenerative ability of these cells, which is a critical factor influencing the success rate of liver surgery and the postoperative survival rate of patients (2). Under physiological conditions, reactive oxygen species (ROS) are continuously generated and cleared in the body, in order to maintain a state of dynamic equilibrium (3). However, the hypoxic environment of ischemic liver cells following HI/R injury promotes the elevated catabolism of adenosine triphosphate, which in turn results in accumulation of the decomposition product, hypoxanthine (4). Furthermore, hypoxia results in inactivation or depletion of endogenous antioxidants, including superoxide dismutase (SOD) (5).

Tumor necrosis factor- $\alpha(\mathrm{TNF}-\alpha)$ is a mononuclear factor that is primarily produced by monocytes and macrophages. TNF- $\alpha$ is able to increase the phagocytosis of neutrophils, promote the secretion of interleukin (IL)-1 and IL- 6 from endothelial cells, and strengthen the adhesion of neutrophils and endothelial cells, thereby stimulating the body to expand local inflammation and the tissue response to injury $(6,7)$. Furthermore, TNF- $\alpha$ may stimulate monocytes and macrophages to secrete IL-1, which in turn further induces the production of TNF- $\alpha$ (8). Following excessive TNF- $\alpha$ production in the acute phase of HI/R injury, due to toxic stimulation within the body, IL-1 serves as a pro-inflammatory cytokine that activates various immune and inflammatory cells (9). The levels of IL-1 not only reflect the extent of the inflammatory response, but also direct clinical treatment (9). IL-6 is secreted by activated macrophages, lymphocytes and epithelial cells, and may be induced by IL-1 $\beta$ and TNF- $\alpha$ (10). Notably, the levels of IL-6 have been demonstrated to decrease following attenuation of HI/R 
injury, thus indicating that IL-6 exists as a result of HI/R injury and has an important role in the development of $\mathrm{HI} / \mathrm{R}$ injury (11).

Paeoniflorin $(\mathrm{PF})$, which is the main active ingredient in the traditional Chinese medicine peony, is a monoterpene glycoside compound. Previous studies have studied the pharmacological effects of PF, and detected activities of the compound, including anti-radical damage, intracellular calcium-overload inhibition and anti-neurotoxicity, as well as numerous biological effects, including blood vessel dilatation, microcirculation improvement, anti-oxidization and anti-convulsion (12-14). Furthermore, Cao et al (15) demonstrated a protective effect of PF on the blood-brain barrier following cerebral ischemia, as well as on local cerebral blood flow and brain edema. Furthermore, it has been indicated that PF may have a significant protective role in focal cerebral ischemic injury, by inhibiting intracellular calcium overload, protecting against free radicals, and improving cerebral vasomotor dysfunction caused by ischemia and anoxia (16). In addition, $\mathrm{PF}$ has been shown to protect the blood-brain barrier following cerebral perfusion during ischemia, and promote the recovery of cerebral blood flow in the early period of reperfusion. PF can also significantly increase SOD levels in rat brain tissue, decrease malondialdehyde (MDA) levels, and alleviate oxidative stress injury in brain tissue caused by cerebral ischemia (16). Previous studies have demonstrated that $\mathrm{PF}$ may markedly reduce the expression levels of nuclear factor (NF)- $\kappa \mathrm{B}(15,17)$. NF- $\kappa \mathrm{B}$ and B-cell lymphoma-2 (Bcl-2) expression levels decreased gradually with increasing PF concentrations (18-20). These studies have also suggested that PF possesses anti-oxidative and anti-apoptotic properties; however, to the best of our knowledge, no previous research has assessed the ability of $\mathrm{PF}$ to relieve $\mathrm{HI} / \mathrm{R}$ in mice. Therefore, the present study aimed to investigate the potential application of $\mathrm{PF}$ in the treatment of $\mathrm{HI} / \mathrm{R}$, as well as to determine the underlying mechanisms.

\section{Materials and methods}

Animals and establishment of HI/R model. Thirty male $\mathrm{BALB} / \mathrm{c}$ mice (age, $6-8$ weeks old, weight, $23 \pm 4 \mathrm{~g}$ ) were maintained in a standard animal laboratory under controlled conditions (light between 7:00 a.m. and 6:00 p.m.; 50-70\% humidity; $24^{\circ} \mathrm{C}$ ) and with ad libitum access to food and water. The mice were purchased from SLAC Laboratory Animal Co., Ltd. (Shanghai, China). All experimental procedures were approved by the Institutional Animal Care and Ethics Committee of The First Affiliated Hospital of Dalian Medical University (Dalian, China).

HI/R method was performed according to previous guidelines, with minor modifications (21-24). Briefly, mice were anesthetized with 99\% ether (Invitrogen, Grand Island, NY, USA). Following anesthesia, the abdomen was shaved and cleansed with $10 \%$ povidone-iodine. Subsequently, mice underwent a median laparotomy. The hepatoportal vein, hepatic artery and hepatic duct were sought out and separated, after which they were clamped for $30 \mathrm{~min}$, and the abdomen was temporarily closed with a suture. Mice were sacrificed by decollation for experimental assays following a $6 \mathrm{~h}$ reperfusion period with an atraumatic vascular clamp, during which

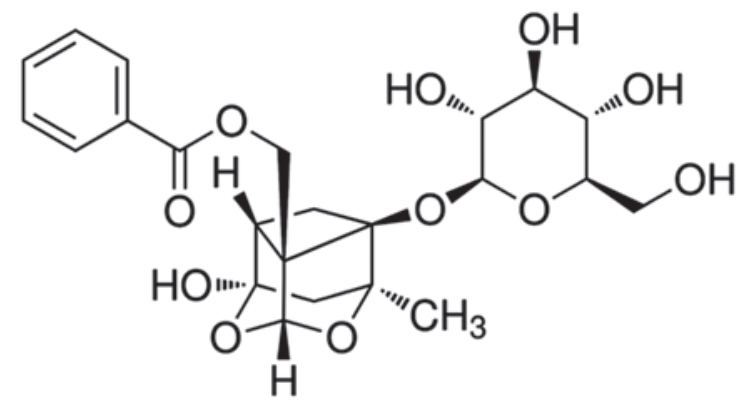

Figure 1. Chemical structure of Paeoniflorin (PF).

they were maintained at a constant temperature via the use of a heated blanket.

Drug preparation. The chemical structure of $\mathrm{PF}$ is shown in Fig. 1. PF (Sigma-Aldrich China, Inc., Shanghai, China), with a purity $>98 \%$, was dissolved in physiological saline, according to the manufacturer's instructions and injected into the tail vein of the mice $5 \mathrm{~min}$ prior to HI/R injury. A total of 30 mice were randomized into five groups, each containing six animals: Sham, Vehicle, and PF treatment groups $(5,10$ and $20 \mathrm{mg} / \mathrm{kg}$ ) (25). The sham (control) group did not undergo the clamping operation, whereas the vehicle group underwent the procedure before injections of the same volume of physiological saline. PF treatment groups underwent the procedure of $\mathrm{HI} / \mathrm{R}$ prior to injection with 5,10 , or $20 \mathrm{mg} / \mathrm{kg}$ of $\mathrm{PF}$ via the tail vein. Following the reperfusion period, and $24 \mathrm{~h}$ following clip removal, the blood and liver samples of all mice were collected and stored at $-80^{\circ} \mathrm{C}$ prior to analysis. Blood samples were taken from the suprahepatic inferior vena cava and were centrifuged at 3,500 $\mathrm{x}$ g for $5 \mathrm{~min}$, in order to obtain serum at room temperature for determination of ALT and AST levels. Liver tissue samples from each animal were measured for hepatic tissue SOD, MDA, glutathione (GSH), glutathione peroxidase (GSH-PX, NF- $\kappa B$, TNF- $\alpha$, IL-1 $\beta$ and IL-6 levels, together with evaluating the activities of caspase-3.

Detection of serum ALT and AST levels. Liver injury was measured by serum levels of ALT and AST. Blood samples were centrifuged at $3,500 \times \mathrm{g}$ for $5 \mathrm{~min}$, in order to obtain serum at room temperature. Serum levels of ALT and AST were measured using an automated analyzer (Model 200; Toshiba, Tokyo, Japan). ALT and AST levels were determined as described previously (26) and expressed as international units per liter (U/1).

$N F-\kappa B, T N F-\alpha, I L-1 \beta$ and IL-6 secretion analysis. Liver tissue was homogenized using a homogenizer (ZW-800D, Wenzhou Weike Biological Laboratory equipment Co., Ltd., Wenzhou, China) and centrifuged at 13,200 x g for $20 \mathrm{~min}$ at $4^{\circ} \mathrm{C}$. Following centrifugation, the supernatant was retained for storage at $-80^{\circ} \mathrm{C}$. Subsequently, $15 \mu \mathrm{g}$ nuclear protein, extracted from liver tissue using a powder with liquid nitrogen and lysed in radioimmunoprecipitation assay buffer, was analyzed, in order to detect NF- $\kappa B$, TNF- $\alpha$, IL- $1 \beta$ and IL-6 levels using commercially available ELISA kits (R\&D Systems, Inc., Minneapolis, MN, USA), and absorbance was 

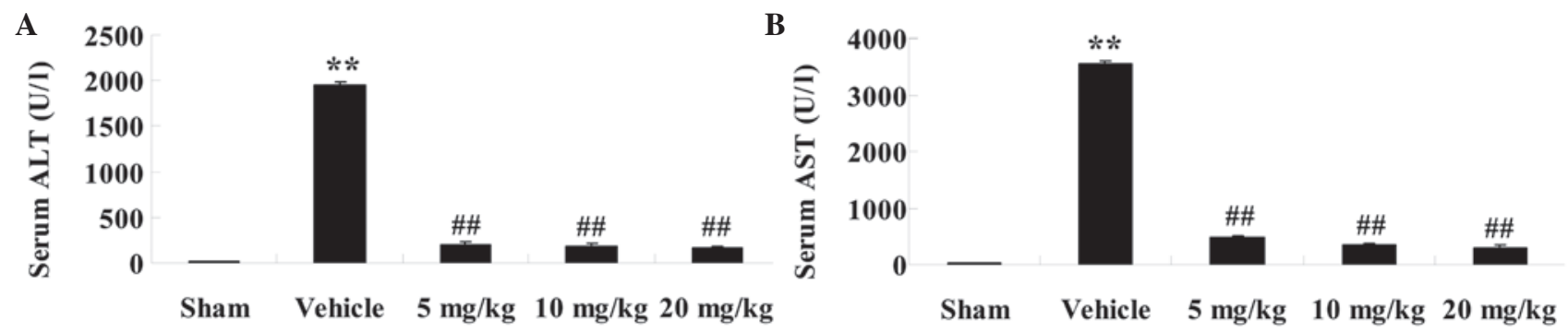

Figure 2. Effects of paeoniflorin (PF) on the serum levels of alanine transaminase (ALT) and aspartate transaminase (AST) $6 \mathrm{~h}$ following a hepatic ischemia/reperfusion injury. The levels of serum (A) ALT and (B) AST were measured in the various groups. Data are presented as the mean \pm standard deviation ( $\mathrm{n}=6)$. ${ }^{* *} \mathrm{P}<0.01$ vs. the sham group; ${ }^{\# \#} \mathrm{P}<0.01$ vs. the vehicle group. Sham, sham-operated; Vehicle, vehicle-treated; $5 \mathrm{mg} / \mathrm{kg}, \mathrm{PF}$ (5 mg/kg)-treated group, $10 \mathrm{mg} / \mathrm{kg}, \mathrm{PF}(10 \mathrm{mg} / \mathrm{kg})$-treated group and $20 \mathrm{mg} / \mathrm{kg}, \mathrm{PF}(20 \mathrm{mg} / \mathrm{kg})$-treated group.

measured using a TECAN Sunrise ELISA Reader (Tecan Group Ltd., Männedorf, Switzerland) at $450 \mathrm{~nm}$.

Assay of SOD, MDA, GSH, and GSH-PX activities. Blood samples were centrifuged at $1,000 \mathrm{xg}$ for $10 \mathrm{~min}$ to obtain serum at room temperature. The supernatant was stored at $-80^{\circ} \mathrm{C}$ until assays for SOD, MDA GSH, and GSH-PX were established. The enzymatic activities of SOD, MDA GSH, and GSH-PX in the serum homogenate was evaluated according to the manufacturer's instructions (Shimadzu Corporation, Kyoto, Japan).

Liver tissue was homogenized using a homogenizer (ZW-800D, Wenzhou Weike Biological Laboratory equipment Co., Ltd.), and the enzymatic activity of SOD in hepatic tissue homogenate was evaluated by determining the rate (U/mg protein) of inhibition of nucleotide oxidation. The level of MDA (nmol/mg protein) in the serum homogenate was measured spectrophotometrically using the Sunrise Remote R-microplate reader at $532 \mathrm{~nm}$. The level of GSH (mmol/mg protein) in the serum homogenate was evaluated by monitoring the reduction of dithiobis-2-nitrobenzoic acid $(4 \mathrm{mg} / \mathrm{ml}$ in methanol), after which, readings were taken spectrophotometrically using the Sunrise Remote R-microplate reader at $412 \mathrm{~nm}$. GSH-PX activity (U/mg protein) in the serum homogenate was determined at the end of the reaction, using the Sunrise Remote R-microplate reader, by measuring absorption at $412 \mathrm{~nm}$.

Analysis of caspase-3 activity. Caspase-3 activity was analyzed $6 \mathrm{~h}$ following HI/R injury. Liver tissue was homogenized using a homogenizer (Haimen Botai Experimental Equipment) and centrifuged at $13,200 \mathrm{x}$ g for $20 \mathrm{~min}$ at $4^{\circ} \mathrm{C}$. Following centrifugation, the supernatant was stored at $-80^{\circ} \mathrm{C}$ for subsequent analysis. In accordance with the manufacturer's instructions, the activity of caspase- 3 was analyzed by the cleavage of chromogenic caspase substrates (Beyotime Institute of Biotechnology, Nantong, China).

Statistical analysis. All results were expressed as the mean \pm standard deviation. Comparisons between groups were performed using Student's t-test and one-way analysis of variance. All statistical analyses were performed using SPSS 15.0 software (SPSS, Inc., Chicago, IL, USA). P<0.05 was considered to indicate a statistically significant difference.

\section{Results}

Treatment with PF reduces serum levels of ALT and AST following HI/R in murine hepatic tissue. Levels of serum ALT in the vehicle group were significantly increased from $18.53 \pm 3.23$ to $1956.53 \pm 34.89 \mathrm{U} / 1(\mathrm{P}<0.01, \mathrm{n}=6) 6 \mathrm{~h}$ following HI/R, as compared with the sham group (Fig. 2A). Following treatment with PF, the levels of serum ALT were significantly reduced from $1956.53 \pm 34.89$ to $200.89 \pm 36.44(5 \mathrm{mg} / \mathrm{kg}$ treatment group, $\mathrm{P}<0.01, \mathrm{n}=6), 189.53 \pm 26.89(10 \mathrm{mg} / \mathrm{kg}$ treatment group, $\mathrm{P}<0.01$, $\mathrm{n}=6)$ and $168.46 \pm 20.14 \mathrm{U} / \mathrm{l}(20 \mathrm{mg} / \mathrm{kg}$ treatment group, $\mathrm{P}<0.01$, $\mathrm{n}=6$ ), as compared with the vehicle group (Fig. 2A). Similarly, the serum levels of AST in the vehicle group were significantly enhanced from $20.58 \pm 3.45$ to $3546.89 \pm 45.89 \mathrm{U} / \mathrm{l}(\mathrm{P}<0.01, \mathrm{n}=6)$ $6 \mathrm{~h}$ following HI/R, as compared with the sham group (Fig. 2B). Conversely, the serum AST levels of the PF-treated groups markedly decreased from $3546.89 \pm 45.89$ to $486.56 \pm 26.78$ $(5 \mathrm{mg} / \mathrm{kg}$ treatment group, $\mathrm{P}<0.01, \mathrm{n}=6), 351.46 \pm 32.89(10 \mathrm{mg} / \mathrm{kg}$ treatment group, $\mathrm{P}<0.01, \mathrm{n}=6)$ and $298.46 \pm 46.11 \mathrm{U} / 1(20 \mathrm{mg} / \mathrm{kg}$ treatment group, $\mathrm{P}<0.01, \mathrm{n}=6)$, as compared with the vehicle group (Fig. 2B).

Treatment with $P F$ relieves $H I / R$ injury via its anti-oxidative activity. In order to corroborate the effects of PF on oxidative stress during HI/R injury of mice, the levels of MDA, and the activities of SOD, GSH and GSH-PX in hepatic tissue were evaluated (Fig. 3A-D). The levels of MDA in the vehicle group were significantly increased from $2.15 \pm 0.12$ to $6.23 \pm 0.52 \mathrm{nmol} / \mathrm{mg}$ protein $(\mathrm{P}<0.01, \mathrm{n}=6) 6 \mathrm{~h}$ following $\mathrm{HI} / \mathrm{R}$, as compared with the sham group (Fig. 3A). Following treatment with $\mathrm{PF}$, the levels of MDA were significantly reduced from $6.23 \pm 0.52$ to $4.12 \pm 0.32(5 \mathrm{mg} / \mathrm{kg}$ treatment group, $\mathrm{P}<0.01, \mathrm{n}=6), 3.62 \pm 0.31(10 \mathrm{mg} / \mathrm{kg}$ treatment group, $\mathrm{P}<0.01, \mathrm{n}=6)$ and $2.89 \pm 0.45 \mathrm{nmol} / \mathrm{mg}$ protein $(20 \mathrm{mg} / \mathrm{kg}$ treatment group, $\mathrm{P}<0.01, \mathrm{n}=6)$, as compared with the vehicle group (Fig. 3A).

Conversely, the activity of SOD in the vehicle group was significantly reduced from $189.36 \pm 5.64$ to $86.89 \pm 8.69 \mathrm{U} / \mathrm{mg}$ protein $(\mathrm{P}<0.01, \mathrm{n}=6) 6 \mathrm{~h}$ following $\mathrm{HI} / \mathrm{R}$, as compared with the sham group (Fig. 3B). In the PF treatment groups, the activity of SOD was significantly enhanced from $86.89 \pm 8.69$ to $114.86 \pm 6.53$ $(5 \mathrm{mg} / \mathrm{kg}$ treatment group, $\mathrm{P}<0.01, \mathrm{n}=6), 126.89 \pm 7.56(10 \mathrm{mg} / \mathrm{kg}$ treatment group, $\mathrm{P}<0.01, \mathrm{n}=6)$, and $149.26 \pm 9.56 \mathrm{U} / \mathrm{mg}$ protein ( $20 \mathrm{mg} / \mathrm{kg}$ treatment group, $\mathrm{P}<0.01, \mathrm{n}=6$ ), as compared with the vehicle group (Fig. 3B). 

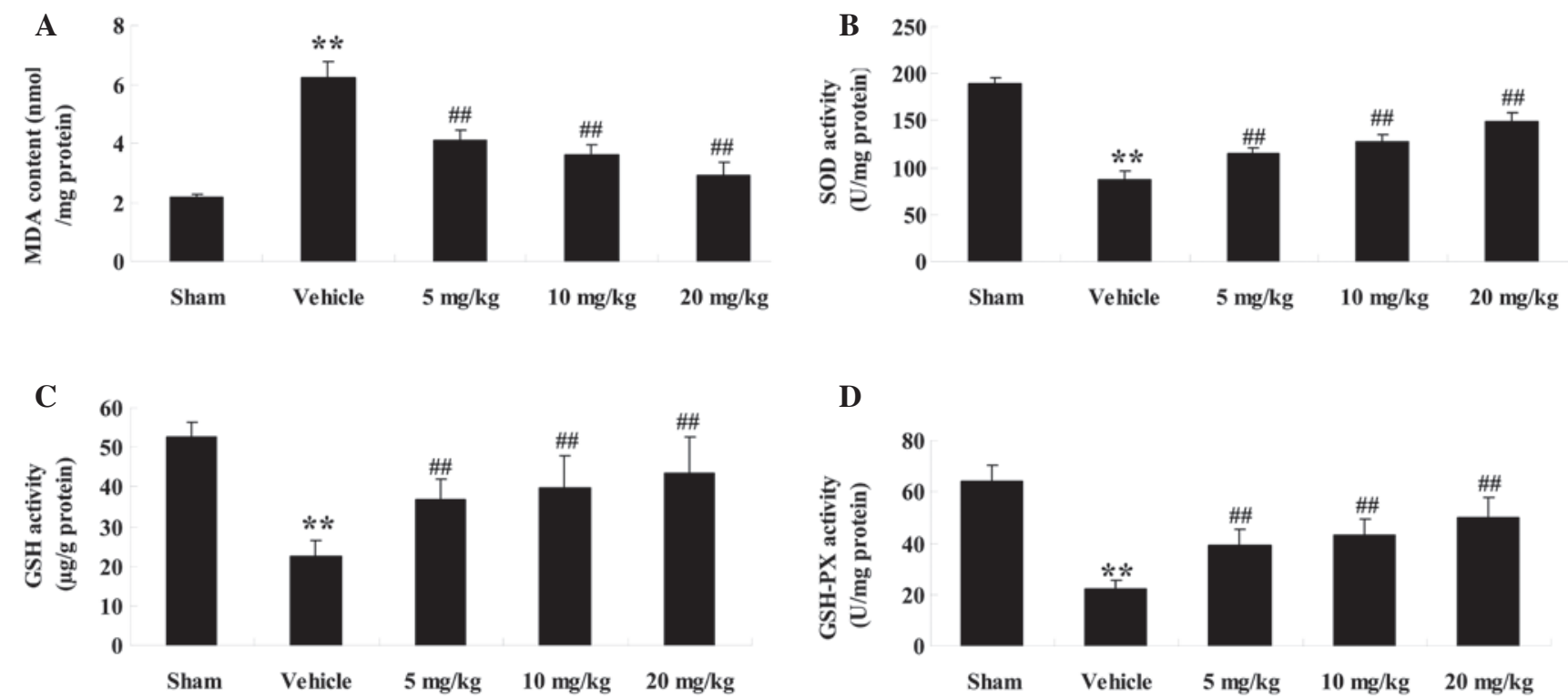

D

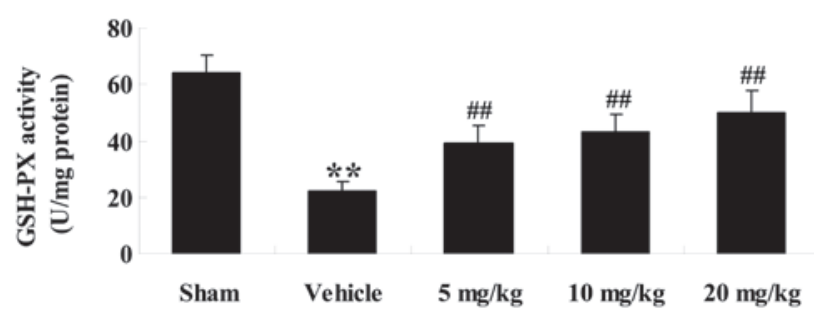

Figure 3. Effects of paeoniflorin (PF) on the levels of malondialdehyde (MDA), and the activity of superoxide dismutase (SOD), glutathione (GSH) and glutatione-peroxidase (GSH-PX) in hepatic tissue $6 \mathrm{~h}$ following hepatic ischemia/reperfusion injury. The levels of (A) MDA, the activity of (B) SOD, (C) GSH and (D) GSH-PX, were detected in the various groups. Data are presented as the mean \pm standard deviation $(\mathrm{n}=6) .{ }^{* *} \mathrm{P}<0.01$ vs. the sham group; ${ }^{\# /} \mathrm{P}<0.01$ vs. the vehicle group. Sham, sham-operated; Vehicle, vehicle-treated; $5 \mathrm{mg} / \mathrm{kg}, \mathrm{PF}(5 \mathrm{mg} / \mathrm{kg}$ )-treated group, $10 \mathrm{mg} / \mathrm{kg}, \mathrm{PF}$ (10 mg/kg)-treated group and $20 \mathrm{mg} / \mathrm{kg}, \mathrm{PF}(20 \mathrm{mg} / \mathrm{kg})$-treated group.
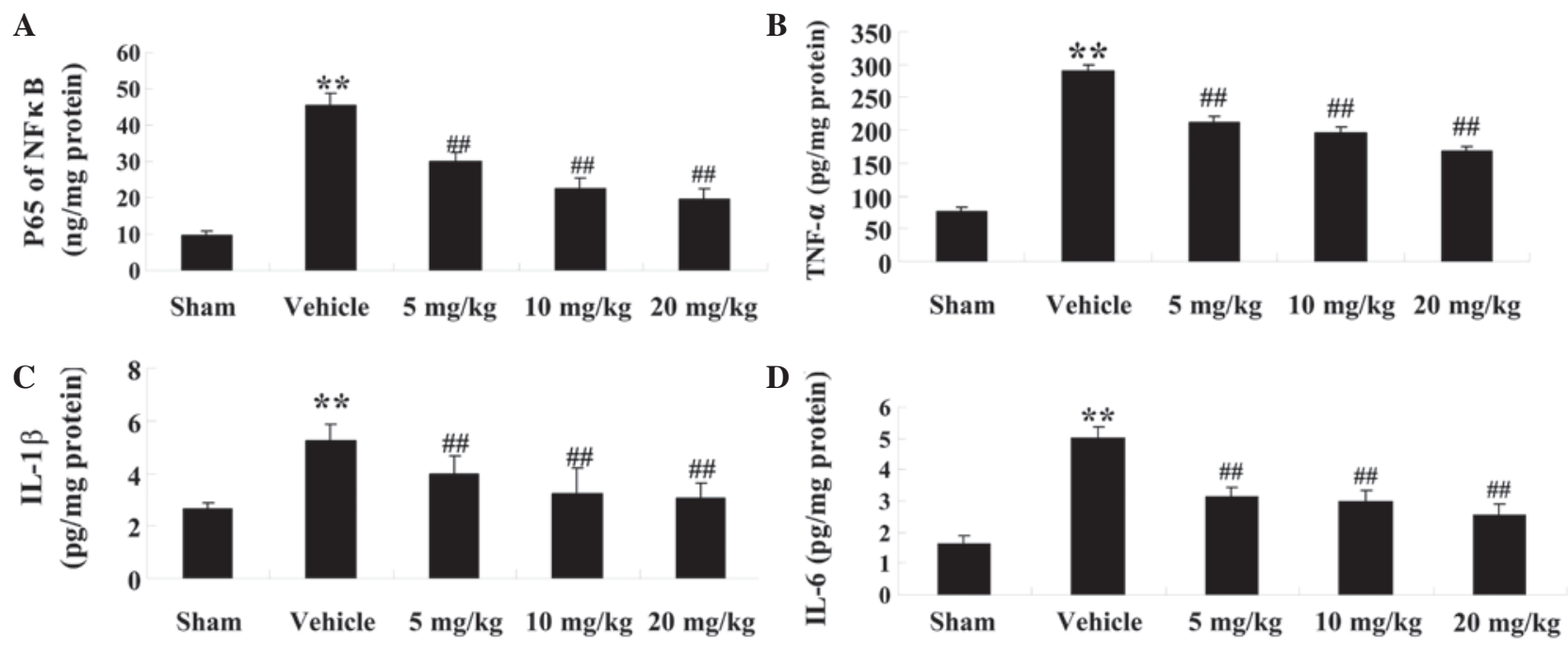

Figure 4. Effects of paeoniflorin (PF) on the expression levels of nuclear factor (NF)- $\mathrm{BB}$, tumor necrosis factor (TNF)- $\alpha$, interleukin (IL)-1 $\beta$ and IL-6 in hepatic tissues $6 \mathrm{~h}$ following hepatic ischemia/reperfusion injury. The expression levels of (A) NF-кB, (B) TNF- $\alpha$, (C) IL-1 $\beta$ and (D) IL-6, were detected in various groups. Data are presented as the mean \pm standard deviation $(\mathrm{n}=6) .{ }^{* *} \mathrm{P}<0.01$ vs. the sham group; ${ }^{\# \#} \mathrm{P}<0.01$ vs. the vehicle group. Sham, sham-operated; Vehicle, vehicle-treated; $5 \mathrm{mg} / \mathrm{kg}, \mathrm{PF}(5 \mathrm{mg} / \mathrm{kg}$ )-treated group, $10 \mathrm{mg} / \mathrm{kg}, \mathrm{PF}(10 \mathrm{mg} / \mathrm{kg}$ )-treated group, and $20 \mathrm{mg} / \mathrm{kg}, \mathrm{PF}$ (20 mg/kg)-treated group.

The contents of GSH in the vehicle group were significantly decreased from $52.63 \pm 3.56$ to $22.56 \pm 4.01 \mu \mathrm{g} / \mathrm{g}$ protein $(\mathrm{P}<0.01, \mathrm{n}=6)$, as compared with the sham group, $6 \mathrm{~h}$ following HI/R(Fig. 3C). Whereas, following PF treatment, the levels of GSH significantly increased to $36.89 \pm 5.01(5 \mathrm{mg} / \mathrm{kg}$ treatment group, $\mathrm{P}<0.01, \mathrm{n}=6), 39.58 \pm 8.23(10 \mathrm{mg} / \mathrm{kg}$ treatment group, $\mathrm{P}<0.01, \mathrm{n}=6)$ and $43.56 \pm 9.26 \mu \mathrm{g} / \mathrm{g}$ protein $(20 \mathrm{mg} / \mathrm{kg}$, treatment group, $\mathrm{P}<0.01, \mathrm{n}=6$ ) (Fig. 3C).

The activity of GSH-PX in the vehicle group declined from $63.89 \pm 6.35$ to $21.86 \pm 3.59 \mathrm{U} / \mathrm{mg}$ protein $(\mathrm{P}<0.01, \mathrm{n}=6)$ as compared with the sham group (Fig. 3D) $6 \mathrm{~h}$ following $\mathrm{HI} / \mathrm{R}$. In the PF treatment groups, the activity of GSH-PX was

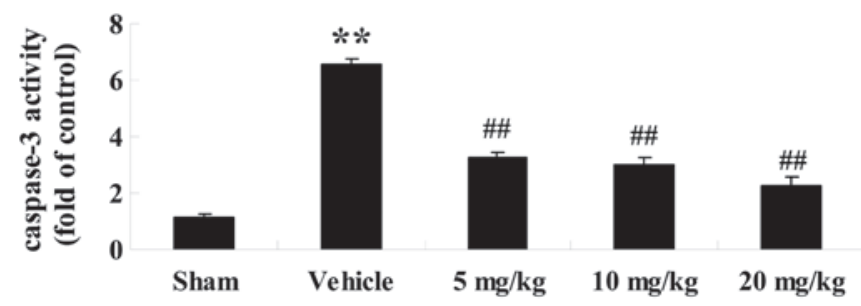

Figure 5. Effects of paeoniflorin (PF) on the caspase-3 activity in hepatic tissues $6 \mathrm{~h}$ following hepatic ischemia/reperfusion. Data are presented as the mean \pm standard deviation $(n=6) .{ }^{* *} \mathrm{P}<0.01$ vs. the sham group; ${ }^{\# \#} \mathrm{P}<0.01$ vs. the vehicle group. Sham, sham-operated; Vehicle, vehicle-treated; $5 \mathrm{mg} / \mathrm{kg}$, PF (5 mg/kg)-treated group, $10 \mathrm{mg} / \mathrm{kg}$, PF (10 mg/kg)-treated group, and $20 \mathrm{mg} / \mathrm{kg}$, PF (20 mg/kg)-treated group. 
significantly increased to $38.95 \pm 6.36(5 \mathrm{mg} / \mathrm{kg}$ treatment group, $\mathrm{P}<0.01, \mathrm{n}=6), 42.98 \pm 6.31(10 \mathrm{mg} / \mathrm{kg}$ treatment group, $\mathrm{P}<0.01$, $\mathrm{n}=6)$ and $49.86 \pm 8.29 \mathrm{U} / \mathrm{mg}$ protein $(20 \mathrm{mg} / \mathrm{kg}$ treatment group, $\mathrm{P}<0.01, \mathrm{n}=6$ ) (Fig. 3D).

Treatment with $P F$ reduces the expression levels of $N F-\kappa B$, $T N F-\alpha, I L-1 \beta$ and $I L-6$ following HI/R in murine hepatic tissue. In order to investigate the effects of PF on inflammatory mediators during $\mathrm{HI} / \mathrm{R}$ injury in mice, the present study evaluated the expression levels of NF- $\kappa \mathrm{B}, \mathrm{TNF}-\alpha, \mathrm{IL}-1 \beta$ and IL-6 in hepatic tissue (Fig. 4A-D). Expression levels of NF- $\mathrm{KB}$ in the vehicle group significantly increased from $9.63 \pm 1.23$ to $45.26 \pm 3.65 \mathrm{ng} / \mathrm{mg}$ protein $(\mathrm{P}<0.01, \mathrm{n}=6) 6 \mathrm{~h}$ following HI/R, as compared with the sham group (Fig. 4A). In the PF treatment groups, the expression of NF- $\mathrm{kB}$ significantly decreased from $45.26 \pm 3.65$ to $29.86 \pm 2.56(5 \mathrm{mg} / \mathrm{kg}$ treatment group, $\mathrm{P}<0.01$, $\mathrm{n}=6), 22.59 \pm 3.01(10 \mathrm{mg} / \mathrm{kg}$ treatment group, $\mathrm{P}<0.01, \mathrm{n}=6)$, and $19.68 \pm 2.99 \mathrm{ng} / \mathrm{mg}$ protein $(20 \mathrm{mg} / \mathrm{kg}$ treatment group, $\mathrm{P}<0.01$, $\mathrm{n}=6$ ), as compared with the vehicle group (Fig. 4A).

Similarly, the expression levels of TNF- $\alpha$ in the vehicle group were increased from $76.56 \pm 6.59$ to $289.65 \pm 8.56$ $\mathrm{pg} / \mathrm{mg}$ protein $(\mathrm{P}<0.01, \mathrm{n}=6)$ as compared with the sham group (Fig. 4B). Following treatment with PF, the expression levels of TNF- $\alpha$ significantly decreased from $289.65 \pm 8.56$ to $210.98 \pm 9.21$ $(5 \mathrm{mg} / \mathrm{kg}$ treatment group, $\mathrm{P}<0.01, \mathrm{n}=6), 195.89 \pm 8.56(10 \mathrm{mg} / \mathrm{kg}$ treatment group, $\mathrm{P}<0.01, \mathrm{n}=6$ ) and $168.56 \pm 6.89 \mathrm{pg} / \mathrm{mg}$ protein $(20 \mathrm{mg} / \mathrm{kg}$ treatment group, $\mathrm{P}<0.01, \mathrm{n}=6$ ), as compared with the vehicle group (Fig. 4B).

The expression levels of IL-1 $\beta$ in the vehicle group were markedly increased from $2.65 \pm 0.25$ to $5.26 \pm 0.59 \mathrm{pg} / \mathrm{mg}$ protein $(\mathrm{P}<0.01, \mathrm{n}=6)$, as compared with the sham group (Fig. $4 \mathrm{C})$. In the PF treatment groups, the expression levels of IL- $1 \beta$ were significantly reduced to $3.99 \pm 0.68(5 \mathrm{mg} / \mathrm{kg}$ treatment group, $\mathrm{P}<0.01, \mathrm{n}=6), 3.25 \pm 0.98(10 \mathrm{mg} / \mathrm{kg}$ treatment group, $\mathrm{P}<0.01$, $\mathrm{n}=6)$ and $3.04 \pm 0.58 \mathrm{pg} / \mathrm{mg}$ protein $(20 \mathrm{mg} / \mathrm{kg}$ treatment group, $\mathrm{P}<0.01, \mathrm{n}=6$ ) (Fig. 4C).

The expression levels of IL-6 in the vehicle group were markedly increased from $1.65 \pm 0.26$ to $5.01 \pm 0.35 \mathrm{mg} / \mathrm{g}$ protein $(\mathrm{P}<0.01, \mathrm{n}=6)$, as compared with the sham group (Fig. 4D). In the PF treatment groups, the expression levels of IL-6 were significantly reduced to $3.14 \pm 0.31(5 \mathrm{mg} / \mathrm{kg}$ treatment group, $\mathrm{P}<0.01, \mathrm{n}=6), 2.98 \pm 0.36(10 \mathrm{mg} / \mathrm{kg}$ treatment group, $\mathrm{P}<0.01$, $\mathrm{n}=6)$ and $2.56 \pm 0.33 \mathrm{pg} / \mathrm{mg}$ protein $(20 \mathrm{mg} / \mathrm{kg}$ treatment group, $\mathrm{P}<0.01, \mathrm{n}=6$ ) (Fig. 4D).

Treatment with $P F$ reduces caspase-3 activity. In order to confirm that PF was able to reduce caspase-3 activity, a colorimetric analysis was conducted (Fig. 5). Caspase-3 activity in the vehicle group was markedly increased to $6.58 \pm 0.16$ ( $P<0.01$, $\mathrm{n}=6$ ), as compared with the sham group. Whereas, in the PF treatment groups $(5,10$ and $20 \mathrm{mg} / \mathrm{kg})$, there was a marked decrease in caspase- 3 activity to $3.25 \pm 0.21(\mathrm{P}<0.01, \mathrm{n}=6)$, $2.98 \pm 0.25(\mathrm{P}<0.01, \mathrm{n}=6)$, and $2.26 \pm 0.31(\mathrm{P}<0.01, \mathrm{n}=6)$, respectively, as compared with the vehicle group.

\section{Discussion}

$\mathrm{PF}$, which is the main active ingredient of the traditional Chinese medicine peony, has been shown to possess numerous biological activities. Previous studies have demonstrated that PF is able to increase SOD levels in ischemic brain tissue, and reduce MDA content (27). In addItion, it has been suggested that PF inhibits the production of free radicals, improves SOD activity in the brain, and decreases MDA content following cerebral ischemia; therefore protecting secondary neurons from injury $(15,28,29)$. PF has a strong anti-inflammatory effect, which has been shown to reduce the enhanced phagocytic function of peritoneal macrophages in rheumatoid arthritis models, and lower levels of TNF- $\alpha$, IL-1 and IL-6 (30-32). Furthermore, PF may reduce the level of lipid oxidation in liver homogenates, and increase the enzymatic activities of SOD and GSH-PX (29). The present study investigated whether PF could reduce HI/R in a murine model. The results of the present study suggested that PF may protect hepatic function from HI/R injury; and the hepatoprotective effect of PF may be associated with its anti-inflammatory and anti-oxidative properties.

$\mathrm{HI} / \mathrm{R}$ injury is not only a predominant cause of poor prognosis in patients with hepatic failure; it also causes oxidative stress injury due to the over-production of ROS. ROS are incredibly volatile and can destroy important structural and functional proteins in cells, potentially causing cell and tissue death. Furthermore, I/R injury may lead to high oxidative stress and oxidative damage of brain tissue. The body responds to the over-production of ROS by increasing the expression levels of antioxidant enzymes, including SOD and catalase. Manipulation of this strategy may become a novel measure for prevention or alleviation of brain injury induced by I/R injury (33). In the present study, the activities of SOD, GSH and GSH-PX in hepatic tissue were significantly higher following treatment with $\mathrm{PF}$, as compared with ischemic mice; however, the levels of MDA were significantly lower. Therefore, the present study demonstrated that PF may relieve HI/R injury via its anti-oxidative activity.

When blood flow is restored, the tissue retrieves oxygen, and this can activate the secretion of related humoral inflammatory mediators in the body due to the stimulation of apoptotic cells, including inflammatory mediators (NF- $\mathrm{KB}, \mathrm{TNF}-\alpha, \mathrm{IL}-1 \beta$ and IL-6), ROS, lipid mediators and peptide media $(7,10,34)$. Activation and release of inflammatory factors is also a key element of HI/R injury. Inflammatory cytokines activate endothelial cells and are involved in the inflammatory process, which stimulates the body to secrete vasoactive components and other media. The media promote leukocyte infiltration into ischemic tissue in order to enhance the production of ROS and other cytotoxic factors; however, these also aggravate the damaged tissue. Reducing the production of inflammatory factors in the HI/R process may reduce injury from reperfusion and, concordantly, inflammatory cells are becoming one of the hotspots in HI/R research. In the present study, the expression levels of NF- $\kappa B$, TNF- $\alpha$, IL- $1 \beta$ and IL- 6 in hepatic tissue were markedly reduced following treatment with $\mathrm{PF}$, as compared with ischemic mice. The present study demonstrated that PF may relieve HI/R injury via its anti-inflammatory activity.

Caspase-3 is regarded as the ultimate mediator of cell apoptosis in the caspase family. Activation of caspase- 3 has been reported to induce apoptosis via endoplasmic reticulum stress, and HI/R may significantly enhance caspase-3 (35). The present study demonstrated the ability of PF to reduce the HI/R injury-induced expression of caspase-3 in hepatic tissue. Consistent with this finding, $\mathrm{PF}$ was also shown to inhibit cellular apoptosis following renal HI/R injury, suggesting that the thera- 
peutic effect of PF may also be associated with its anti-apoptotic action in ischemic mice, as well as its anti-inflammatory activity.

In conclusion, the present data demonstrated that PF was able to attenuate HI/R injury by minimizing oxidative and inflammatory stress and by decreasing the expression of apoptosis-associated proteins. Therefore, the hepatoprotective effect of PF in a HI/R mouse model may be related to its anti-oxidative, anti-inflammatory and/or anti-apoptotic properties.

\section{Acknowledgements}

The present study was financially supported by the first batch of the 2012 Liaoning Province Science and Technology Plan Project (grant. no. 2012225020) and Dalian City Technology Bureau in 2014 (grant. no. 2014E14SF188).

\section{References}

1. Grossini E, Pollesello P, Bellofatto K, Sigaudo L, Farruggio S, Origlia V,Mombello C,Mary DA, Valente G and Vacca G: Protective effects elicited by levosimendan against liver ischemia/reperfusion injury in anesthetized rats. Liver Transpl 20: 361-375, 2014.

2. Çekın AH, Gür G, Türkoğlu S, Aldemır D, Yilmaz U, Gürsoy M, Taşkoparan $\mathrm{M}$ and Boyacioğlu S: The protective effect of L-carnitine on hepatic ischemia-reperfusion injury in rats. Turk J Gastroenterol 24: 51-56, 2013.

3. Suzuki M, Takeuchi H, Kakita T, Unno M, Katayose Y and Matsuno S: The involvement of the intracellular superoxide production system in hepatic ischemia-reperfusion injury. In vivo and in vitro experiments using transgenic mice manifesting excessive CuZn-SOD activity. Free Radic Biol Med 29: 756-763, 2000.

4. Cheng P, Wang F, Chen K, Shen M, Dai W, Xu L, Zhang Y, Wang C, Li J, Yang J, et al: Hydrogen sulfide ameliorates ischemia/reperfusion-induced hepatitis by inhibiting apoptosis and autophagy pathways. Mediators Inflamm 2014: 935251, 2014.

5. Ramachandran S, Liaw JM, Jia J, Glasgow SC, Liu W, Csontos K, Upadhya GA, Mohanakumar T and Chapman WC: Ischemia-reperfusion injury in rat steatotic liver is dependent on NFkappaB P65 activation. Transpl Immunol 26: 201-206, 2012.

6. Kamo N, Ke B, Ghaffari AA, Shen XD, Busuttil RW, Cheng G and Kupiec-Weglinski JW: ASC/caspase-1/IL-1 $\beta$ signaling triggers inflammatory responses by promoting HMGB1 induction in liver ischemia/reperfusion injury. Hepatology 58: 351-362, 2013.

7. Zhu Y, Dang S and Hua Z: Advanced achievements about neuroprotective mechanisms of paeoniflorin. Zhongguo Zhong Yao Za Zhi 35: 1490-1493, 2010 (In Chinese).

8. Ding MP, Feng F and Hu HT: Effects of puerarin on expression of nuclear factor kappaB after cerebral ischemia/reperfusion in rats Zhongguo Zhong Yao Za Zhi 32: 2515-2518, 2007 (In Chinese).

9. Hu W, Zhang Q, Yang X, Wang Y and Sun L: Puerarin inhibits adhesion molecule expression in tnf-alpha-stimulated human endothelial cells via modulation of the nuclear factor kappaB pathway. Pharmacology 85: 27-35, 2010.

10. Hino H, Takahashi H, Suzuki Y, Tanaka J, Ishii E and Fukuda M: Anticonvulsive effect of paeoniflorin on experimental febrile seizures in immature rats: Possible application for febrile seizures in children. PLoS One 7: e42920, 2012.

11. Guo RB, Wang GF, Zhao AP, Gu J, Sun XL and Hu G: Paeoniflorin protects against ischemia-induced brain damages in rats via inhibiting MAPKs/NF- $\mathrm{kB}$-mediated inflammatory responses. PLoS One 7: e49701, 2012.

12. Liu DZ, Zhao FL, Liu J, Ji XQ, Ye Y and Zhu XZ: Potentiation of adenosine A1 receptor agonist CPA-induced antinociception by paeoniflorin in mice. Biol Pharm Bull 29: 1630-1633, 2006.

13. Shen XD, Ke B, Zhai Y, Gao F, Anselmo D, Lassman CR, Busuttil RW and Kupiec-Weglinski JW: Stat4 and Stat6 signaling in hepatic ischemia/reperfusion injury in mice: HO-1 dependence of Stat 4 disruption-mediated cytoprotection. Hepatology 37: 296-303, 2003.

14. Uchida Y, Ke B, Freitas MC, Ji H,Zhao D, Benjamin ER, Najafian N, Yagita H, Akiba H, Busuttil RW and Kupiec-Weglinski JW: The emerging role of T-cell immunoglobulin mucin-1 in the mechanism of liver ischemia and reperfusion injury in the mouse. Hepatology 51: 1363-1372, 2010.
15. Cao C, He X, Wang W, Zhang L, Lin H and Du L: Kinetic distribution of paeoniflorin in cortex of normal and cerebral ischemia-reperfusion rats after intravenous administration of Paeoniae Radix extract. Biomed Chromatogr 20: 1283-1288, 2006.

16. Uchida Y, Freitas MC, Zhao D, Busuttil RW and Kupiec-Weglinski JW: The protective function of neutrophil elastase inhibitor in liver ischemia/reperfusion injury. Transplantation 89: 1050-1056, 2010.

17. Sun R, Yi YP, Lv LL, Zhang ZP, Sun H and Liu GQ: Effects of paeoniflorin on pathological changes in global brain ischemia model rats. Zhongguo Zhong Yao Za Zhi 32: 2518-2522, 2007 (In Chinese).

18. Yu J, Zhu X, Qi X, Che J and Cao B: Paeoniflorin protects human EA.hy926 endothelial cells against gamma-radiation induced oxidative injury by activating the NF-E2-related factor $2 /$ heme oxygenase-1 pathway. Toxicol Lett 218: 224-234, 2013.

19. Jiang Z, Chen W, Yan X, Bi L, Guo S and Zhan Z: Paeoniflorin protects cells from GalN/TNF- $\alpha$-induced apoptosis via ER stress and mitochondria-dependent pathways in human L02 hepatocytes. Acta Biochim Biophys Sin (Shanghai) 46: 357-367, 2014.

20. Kong P, Chi R, Zhang L, Wang N and Lu Y: Effects of paeoniflorin on tumor necrosis factor- $\alpha$-induced insulin resistance and changes of adipokines in 3T3-L1 adipocytes. Fitoterapia 91: 44-50, 2013.

21. Zheng YQ, Wei W, Zhu L and Liu JX: Effects and mechanisms of Paeoniflorin, a bioactive glucoside from paeony root, on adjuvant arthritis in rats. Inflamm Res 56: 182-188, 2007.

22. He SQ, Zhang YH, Venugopal SK, Dicus CW, Perez RV, Ramsamooj R, Nantz MH,Zern MA and Wu J: Delivery of antioxidative enzyme genes protects against ischemia/reperfusion-induced liver injury in mice. Liver Transpl 12: 1869-1879, 2006.

23. Kim J, Kim HY and Lee SM: Protective effects of geniposide and genipin against hepatic ischemia/reperfusion injury in mice. Biomol Ther (Seoul) 21: 132-137, 2013.

24. Underhill DM, Rossnagle E, Lowell CA and Simmons RM: Dectin-1 activates Syk tyrosine kinase in a dynamic subset of macrophages for reactive oxygen production. Blood 106: 2543-2550, 2005.

25. Yun N, Kang JW and Lee SM: Protective effects of chlorogenic acid against ischemia/reperfusion injury in rat liver: Molecular evidence of its antioxidant and anti-inflammatory properties. J Nutr Biochem 23: 1249-1255, 2012.

26. Zetzmann CP, Swamy OR, Loss GE Jr, Bohorquez H and Cohen AJ: Improving Donor Livers by Inhibiting TNF- $\alpha$ Production. Ochsner J 10: 250-255, 2010.

27. Teoh N, Leclercq I, Pena AD and Farrell G: Low-dose TNF-alpha protects against hepatic ischemia-reperfusion injury in mice: Implications for preconditioning. Hepatology 37: 118-128, 2003.

28. Pan S, Liu L, Pan H, Ma Y, Wang D, Kang K, Wang J, Sun B, Sun $\mathrm{X}$ and Jiang H: Protective effects of hydroxytyrosol on liver ischemia/reperfusion injury in mice. Mol Nutr Food Res 57: 1218-1227, 2013.

29. Lan Z, Chen L, Fu Q, Ji W, Wang S, Liang Z, Qu R, Kong L and Ma S: Paeoniflorin attenuates amyloid-beta peptide-induced neurotoxicity by ameliorating oxidative stress and regulating the NGF-mediated signaling in rats. Brain Res 1498: 9-19, 2013.

30. Chen T, Guo ZP, Jiao XY, Jia RZ, Zhang YH, Li JY, Huang XL and Liu HJ: Peoniflorin suppresses tumor necrosis factor- $\alpha$ induced chemokine production in human dermal microvascular endothelial cells by blocking nuclear factor- $\kappa \mathrm{B}$ and ERK pathway. Arch Dermatol Res 303: 351-360, 2011.

31. Chen T, Guo ZP, Wang L, Qin S, Cao N, Li MM, Jia RZ and Wang TT: Paeoniflorin suppresses vascular damage and the expression of E-selectin and ICAM-1 in a mouse model of cutaneous Arthus reaction. Exp Dermatol 22: 453-457, 2013.

32. Rao ML, Tang M, He JY and Dong Z: Effects of paeoniflorin on cerebral blood flow and the balance of PGI2/TXA2 of rats with focal cerebral ischemia-reperfusion injury. Yao Xue Xue Bao 49: 55-60, 2014 (In Chinese).

33. Gündüz E, Dursun R, Zengin Y, İçer M, Durgun HM, Kanıcı A, Kaplan İ, Alabalık U, Gürbüz H and Güloğlu C: Lycium barbarum extract provides effective protection against paracetamol-induced acute hepatotoxicity in rats. Int J Clin Exp Med 8: 7898-7905, 2015.

34. Yu J, Zhu X, Qi X, Che J and Cao B: Paeoniflorin protects human EA.hy926 endothelial cells against gamma-radiation induced oxidative injury by activating the NF-E2-related factor $2 /$ heme oxygenase-1 pathway. Toxicol Lett 218: 224-234, 2013.

35. Kim HY and Lee SM: Ferulic acid attenuates ischemia/reperfusioninduced hepatocyte apoptosis via inhibition of JNK activation. Eur J Pharm Sci 45: 708-715, 2012. 